6. Galloway, J. N. in The Biogeochemical Cycling of Sulfur and Nitrogen in the Remote Atmosphere (eds Galloway, J. N., Charlson, R. J., Andrae, M. O. \& Rodhe, H.) (Reidel, Dordrecht, in the press)

7. Galloway, J. N., Knap, A. H. \& Church, T. M. J. geophys. Res. 88, 10859-10864 (1983)

8. Wright, W. R. \& Knap, A. H. Intergovtl oceanogr. Commn Tech. Ser. 24 (1983).

9. Jenkins, W. J. \& Goldman, J. C. J. mar. Res. 43, 465-491 (1985).

10. Galloway, J. N., Likens, G. E., Keene, W. C. \& Miller, J. J. geophys. Res. 87, 8771-8786 (1982)

11. Keene, W. C., Pszenny, A. A. P., Galloway, J. N. \& Hawley, M. E. J. geophys. Res. (submitted).

2. Jickells, T. D. \& Hillier, G. B. in Bermuda biol. Stn Spec. Publ. No. 18, 63-66 (1982).

3. Redfield, A. C., Ketchum, B. H. \& Richards, F. A. in The Sea Vol. 2 (ed. Hill, M. N.) (Interscience, London, 1963)

14. Takahashi, T. Broeker, W. S. \& Langer, S. J geophys. Res. 90, 6907-6924 (1985).

15. Dugdale, R. C. \& Goering, J. J. Limnol. Oceanogr. 12, 196-206 (1967).

16. Klein, P. \& Coste, B. Deep Sea Res. 31, 21-37 (1984).

17. Carpenter, E. D. \& McCarthy, J. J. Limnol. Oceanogr. 20, 389-401 (1975)

18. Menzel, D. W. \& Spaeth, J. P. Limnol. Oceanogr. 7, 159-162 (1962).

19. McCarthy, J. J. \& Carpenter, E. D. Nitrogen in the Marine Environment (eds Carpenter, E. J. \& Capone, D. G.) 487-512 (Academic, New York, 1983).

\section{Isoprenoid thiophenes: novel products of sediment diagenesis?}

\section{S. C. Brassell*, C. A. Lewis*, J. W. de Leeuw†, F. de Lange $\dagger$ \& J. S. Sinninghe Damsté $\dagger$}

* Organic Geochemistry Unit, University of Bristol, School of Chemistry, Cantock's Close, Bristol BS8 1TS, UK † Organic Geochemistry Unit, Delft University of Technology, Department of Chemistry and Chemical Engineering, de Vries van Heystplantsoen 2, 2628 RZ Delft, The Netherlands

Sulphur is a significant component of the organic matter in recent and ancient sediments and in petroleums ${ }^{1,2}$, yet the precise nature of its association and incorporation is poorly understood. Various sulphur-containing compounds have been recognized in petroleums ${ }^{2-4}$, but little is known about their origins and mode of generation during sediment burial, and for only a few organosulphur compounds with $>15$ carbon atoms have the structures been determined $^{5,6}$. Here we identify one of the alkyl thiophenes which occur widely in both recent and ancient deep-sea sediments $^{7-13}$ as 3-methyl-2-(3,7,11-trimethyldodecyl)-thiophene, occurring as a limited number of the possible stereoisomers. This compound is presumed to originate from the incorporation of sulphur into chlorophyll-derived phytol, or archaebacterial phytenes or their diagenetic products. Its recognition suggests a novel diagenetic pathway for acyclic isoprenoids involving the introduction of sulphur into specific lipid moieties. Similar, but intermolecular, sulphur incorporation might give rise to sulphurlinked macromolecular materials and thereby contribute significantly to the formation of kerogens.

Significant developments have recently occurred in the understanding of the biological origins of sedimentary acyclic isoprenoids and their subsequent diagenetic fate. It is now evident that such compounds, which were among the first clearly related to natural products to be recognized in sediments and petroleums ${ }^{14,15}$, are not wholly derived from the phytyl sidechain of chlorophyll, but may also originate from the free and ether-bound lipids of archaebacteria ${ }^{16-18}$ and from the tocopherols ${ }^{19}$ of photosynthetic organisms. Here we further expand the range of such compounds with the characterization of acyclic isoprenoid thiophenes in sediments.

In addition to a thiophene-containing hopane ${ }^{6}$, many immature sediments, notably those recovered by the Deep Sea Drilling Project (DSDP), contain a number of components tentatively identified as thiophenes from their mass spectra ${ }^{7-10}$ (Table 1, Fig. 1). These spectra are dominated by cleavages and rearrangements associated with the thiophene ring ${ }^{20,21}$, a feature that simplifies the recognition of the size of their alkyl substituents, although providing no indication of the structure of these alkyl groups (whether straight-chain or branched). The widespread occurrence and relative abundance of the $\mathrm{C}_{20}$ alkyl thiophenes I and II suggested to us that these compounds might be related to acyclic isoprenoids. Certainly their occurrence in several sediments (for example, in the Japan Trench, Walvis Ridge and Cariaco Trench) with high concentrations of phytenes $^{22}$ and phytol ${ }^{23}$ provided circumstantial evidence for this relationship.

If I (Table 1, Fig. 1) is an acyclic isoprenoid thiophene, then its mass spectrum ${ }^{9}$ might correspond to that expected for 3 methyl-2-(3,7,11-trimethyldodecyl)-thiophene (Fig. 2). Synthesis of this compound (together with its 4-methyl isomer, III; Fig. 3 ) followed by gas chromatograph (GC) and gas chromatograph-mass spectrometer (GC-MS) coinjection (OV-1 methyl silicone fluid columns) confirmed this assignment. Such a structure might arise from the incorporation of sulphur into a phytadiene or phytol, a process also observed in heating experiments with $\mathrm{H}_{2} \mathrm{~S}$ and carbohydrates ${ }^{24}$. The recognition of alkyl

Table 1 Occurrence of alkylthiophenes in oceanic and other sediments

\begin{tabular}{|c|c|c|c|c|c|c|}
\hline \multirow[b]{2}{*}{ Location } & \multirow{2}{*}{$\begin{array}{c}\text { DSDP } \\
\text { Leg-Site }\end{array}$} & \multicolumn{5}{|c|}{ Compounds } \\
\hline & & Age & I & II & Others* & Ref. \\
\hline Cariaco Trench & $15-147$ & Quaternary & $\sqrt{ }$ & $\sqrt{ }$ & - & $\ddagger$ \\
\hline Japan Trench & $56-436$ & Pliocene & - & - & $\mathrm{F}$ & $\ddagger$ \\
\hline San Miguel Gap & $63-467$ & Plio.-Mio. & $\sqrt{ }$ & $\sqrt{ }$ & $\mathrm{F}$ & 7 \\
\hline \multirow[t]{2}{*}{ Gulf of California } & $64-474$ & Pleistocene & - & - & $\mathrm{F}$ & 8 \\
\hline & $64-478$ & Pleistocene & - & - & $\mathrm{G}, \mathrm{H}$ & 8 \\
\hline Middle America Trench & $67-496$ & Quaternary & $\sqrt{ }$ & $\sqrt{ }$ & - & $\ddagger$ \\
\hline Walvis Ridge & $75-532$ & Quat.-Plio. & $\sqrt{ }$ & $\sqrt{ }$ & A-F & $9, \ddagger$ \\
\hline Angola Basin & $75-530$ & Miocene & $\sqrt{ }$ & $\sqrt{ }$ & $\mathrm{F}$ & 9 \\
\hline \multirow{2}{*}{ Mazagan Escarpment } & $79-545$ & Cenomanian & $\sqrt{ }$ & - & - & 10 \\
\hline & $79-547$ & Eocene & $\sqrt{ }$ & $\sqrt{ }$ & - & 10 \\
\hline Livello Bonarelli & NA & Cen./Tur. & $\sqrt{ }$ & $\sqrt{ }$ & - & 11 \\
\hline Namibian Shelf & NA & Quaternary & $\sqrt{ }$ & $\sqrt{ }$ & - & 12 \\
\hline
\end{tabular}

—, Not observed or reported; NA, not applicable. Pleist., Pleistocene; Mio., Miocene, Quat., Quaternary; Plio., Pliocene; Cen., Cenomanian; Tur., Turonian.

* The identities of compounds $\mathrm{A}$ to $\mathrm{F}$ are given in the legend of Fig. $1 ; \mathrm{G}$ and $\mathrm{H}$ are isomeric $\mathrm{C}_{25}$ alkylthiophenes $\left(\mathrm{M}^{+}=378\right.$, prominent ions with mass/charge ratios $m / z=265$ and 125 (ref. 8)) of unknown structure.

$\dagger$ Range of mono-, di- and trialkylated thiophenes.

$\ddagger$ S.C.B., unpublished data. 
Fig. 1 Reconstituted ion chromatogram from GC-MS analysis of the extractable aliphatic hydrocarbon fraction of a diatomaceous ooze from Walvis Ridge (DSDP 75-532-42-3, 173-m sub-bottom depth). Insets $a, b$ and $c$ are expansions of the scan regions $1,050-1,300$, $1,900-2,000$ and $2,100-2,200$, respectively. This sample contains a number of alkyl thiophenes distinguished by the prominence of $m / z=97$, 98,111 or 125 in their mass spectra. Compounds I and II are discussed in the text; their mass spectra for molecular ion fragment mass $\left(\mathrm{M}^{+}\right) 308$ are dominated by $\mathrm{m} / \mathrm{z}$ of 111 and 98, respectively, and are published in ref. 10 . $\mathrm{A}, \mathrm{D}, \mathrm{E}$ and $\mathrm{F}$ appear to be $\mathrm{C}_{18}, \mathrm{C}_{19}, \mathrm{C}_{25}$ and $\mathrm{C}_{27} n$-alkyl substituted thiophenes. The mass spectrum of $F\left(M^{+}=406\right)$ is given in ref. 9. The minor constituents $\mathrm{B}$ and $\mathrm{C}$ are probably 2,3 dimethyl - $5-(2,6,10$ - trimethylundecyl $)$ thiophene $\mathrm{e}^{13}$ and 3,5-dimethyl-2-(3,7,11trimethyldodecyl)-thiophene, respectively (Fig. 2). Peaks corresponding to $n$-alkanes are designated by their carbon numbers; among other significant components note the abundance of three phytene isomers between scans 700 and 800. The GC-MS conditions were similar to those previously reported ${ }^{29}$.

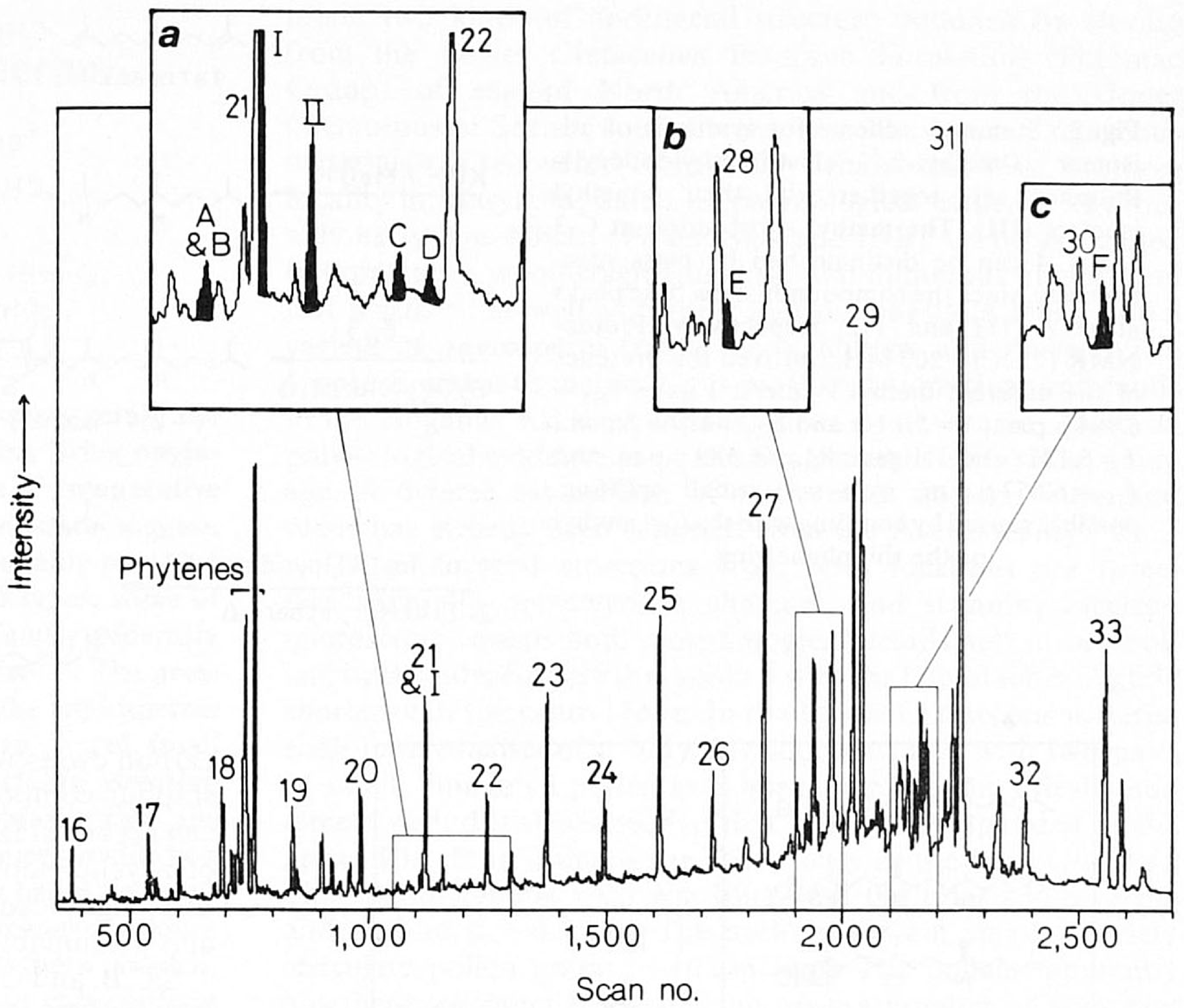

thiophenes in shallow, immature sediments (Table 1) suggests, however, that elevated temperatures are not required for their formation. Rather, their occurrence in oceanic sediments is more closely analogous to that of various low-molecular-weight organo-sulphur compounds, including dimethylsulphide and volatile thiophenes ${ }^{25}$, which are deemed to be direct metabolic products. A biosynthetic origin of higher-molecular-weight thiophenes, such as I, cannot be fully excluded.

A useful method for assessing the origins and extent of thermal maturation of acyclic isoprenoids is the evaluation of the steric configuration at their chiral centres. Comparative GC on a

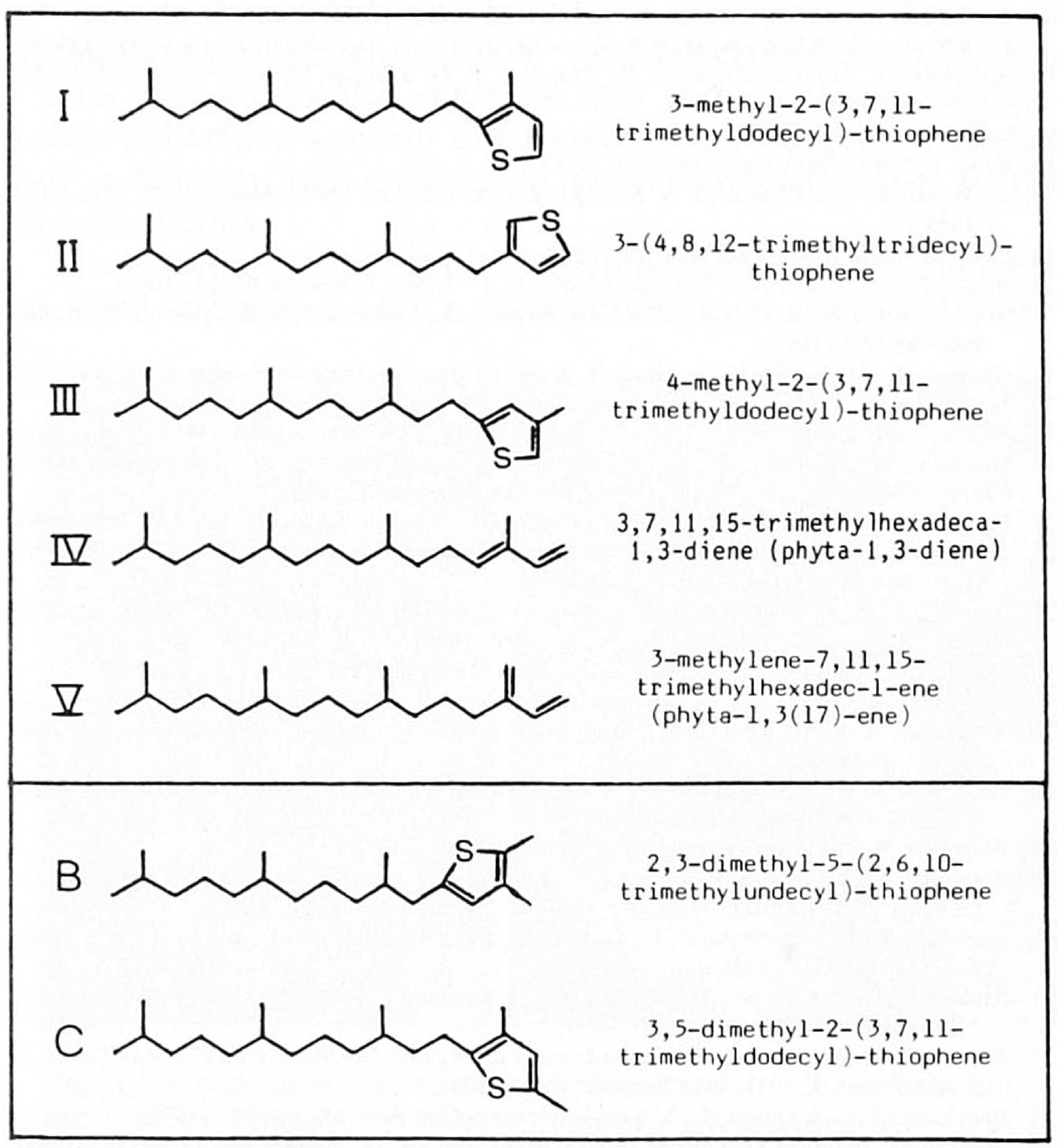

Fig. 2 Structures of compounds cited in the text and figures. diethylene glycol succinate/polyethylene glycol succinate (DEGS/PEGS)-coated column ${ }^{26}$ showed that the naturally occurring compound in a calcareous clay from the Cariaco Trench was composed of a maximum of two of the four possible stereoisomers (Ia-d, Fig. 4) found in the all-isomer synthetic product. It also seems probable from this analysis that the naturally occurring $\mathrm{I}$ in the Cariaco Trench sediment is composed, at least in part, of the isomer (3R,7R; Ia in Fig. 4) expected to derive from isoprenoid biosynthesis, although proof of this requires stereospecific synthesis in the laboratory. The structure and limited stereochemistry of $\mathrm{I}$ is consistent with sulphur incorporation into phyta-1,3-diene (IV in Fig. 2) or phytol.

By analogy with the mass spectrum of I (ref. 9), compound II (Table 1, Fig. 1) would correspond to 3-(4,8,12-trimethyltridecyl)-thiophene, which might arise from sulphur incorporation into phyta-1,3(17)-diene (V in Fig. 2) or phytol. Such phytadienes, and hence isoprenoid thiophenes, cannot be artefacts generated during sample preparation because wet extraction methods were used ${ }^{27}$. Given the widespread occurrence of I and II, and other $n$-alkyl and isopranyl substituted thiophenes (ref. 13 and S.C.B., unpublished data), in oceanic sediments (Table 1), there appears to be a general metabolic or diagenetic process which results in the introduction of sulphur into lipid moieties. The precise mechanism and biological or chemical agents of this process are unclear, but $\mathrm{H}_{2} \mathrm{~S}$ or polysulphides may be involved. Perhaps it is a side reaction associated with bacterial sulphate reduction, which certainly occurs or has occurred in the sediments found to contain thiophenes.

For the thiophenes discussed here, the sulphur introduced into the acyclic isoprenoids is bonded intramolecularly. Similar reactions operating in an intermolecular fashion would give rise to sulphur-linked polymeric material within kerogens. Such bonding may survive in petroleums and occur in both their aromatic and asphaltene fractions; especially the latter since it is rich in sulphur. Alternatively, thermal breaking of carbonsulphur bonds may be a significant contributory process in the generation of petroleum from kerogen. The clear indication that sulphur incorporation can affect organic compounds during early diagenesis represents a major advance in the understanding of interactions at the molecular level between the sulphur and 


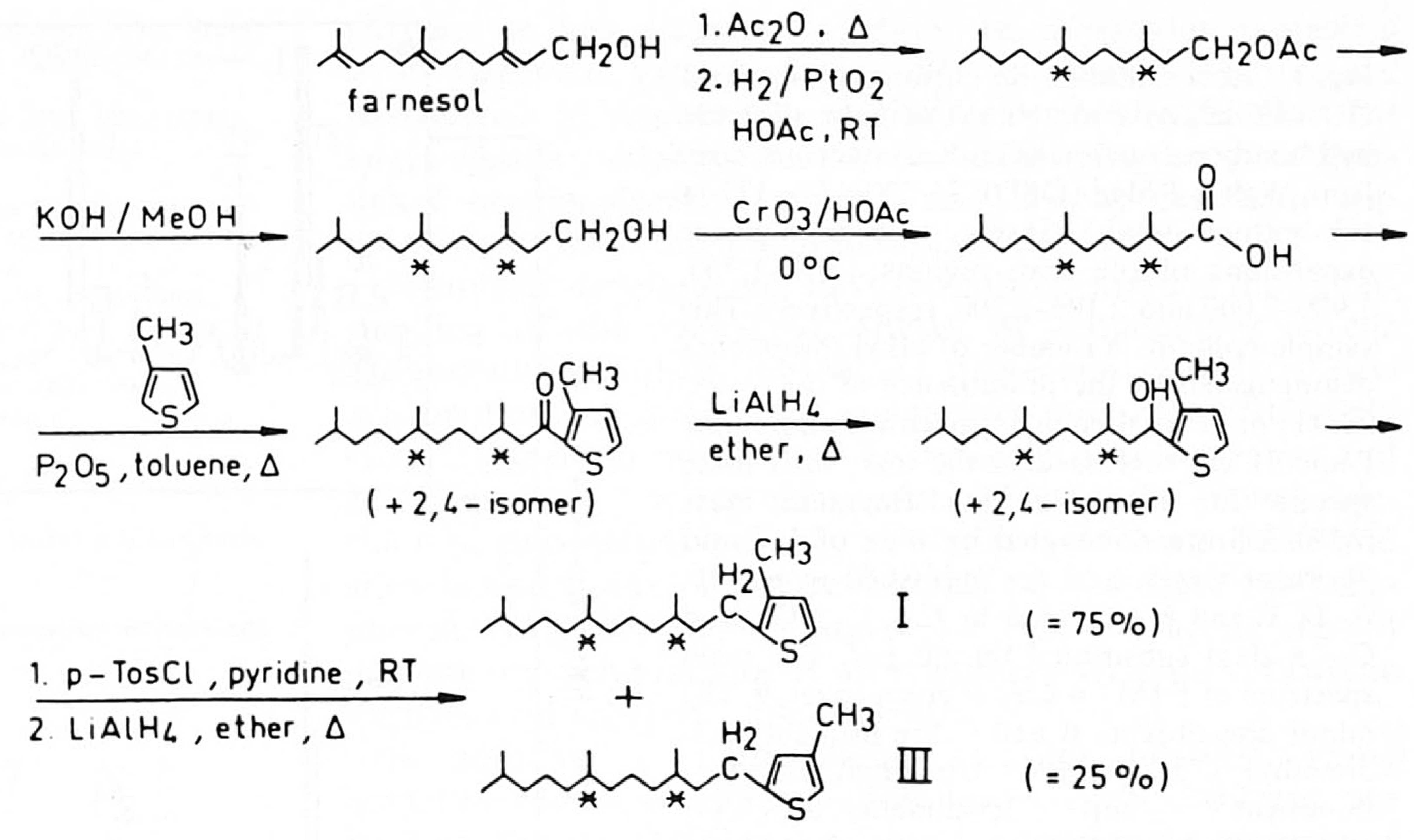

Fig. 3 Summary scheme for synthesis of allisomer 3-methyl-2-(3,7,11-trimethyldodecyl)thiophene (I) together with their 4-methyl isomers (III). The methyl substitution at C-3 and $\mathrm{C}-4$ can be distinguished by mass spectrometry, since the compounds show base peaks at $m / z=111$ and 112 , respectively. ProtonNMR $\left(\mathrm{CDCl}_{3}, 200 \mathrm{MHz}\right)$ proved the presence of the different methyl isomers: I gave $\delta_{\mathrm{H} 5}=$ 6.984 p.p.m., $J=5.1 \mathrm{~Hz}$ and $\delta_{\mathrm{H} 4}=6.766$ p.p.m., $J=5.1 \mathrm{~Hz}$ and III gave $\delta_{\mathrm{H} 3}=6.589$ p.p.m. and $\delta_{\mathrm{H} 5}=6.657$ p.p.m. with very small splitting, possibly caused by coupling with the C-4 methyl of the thiophene ring.

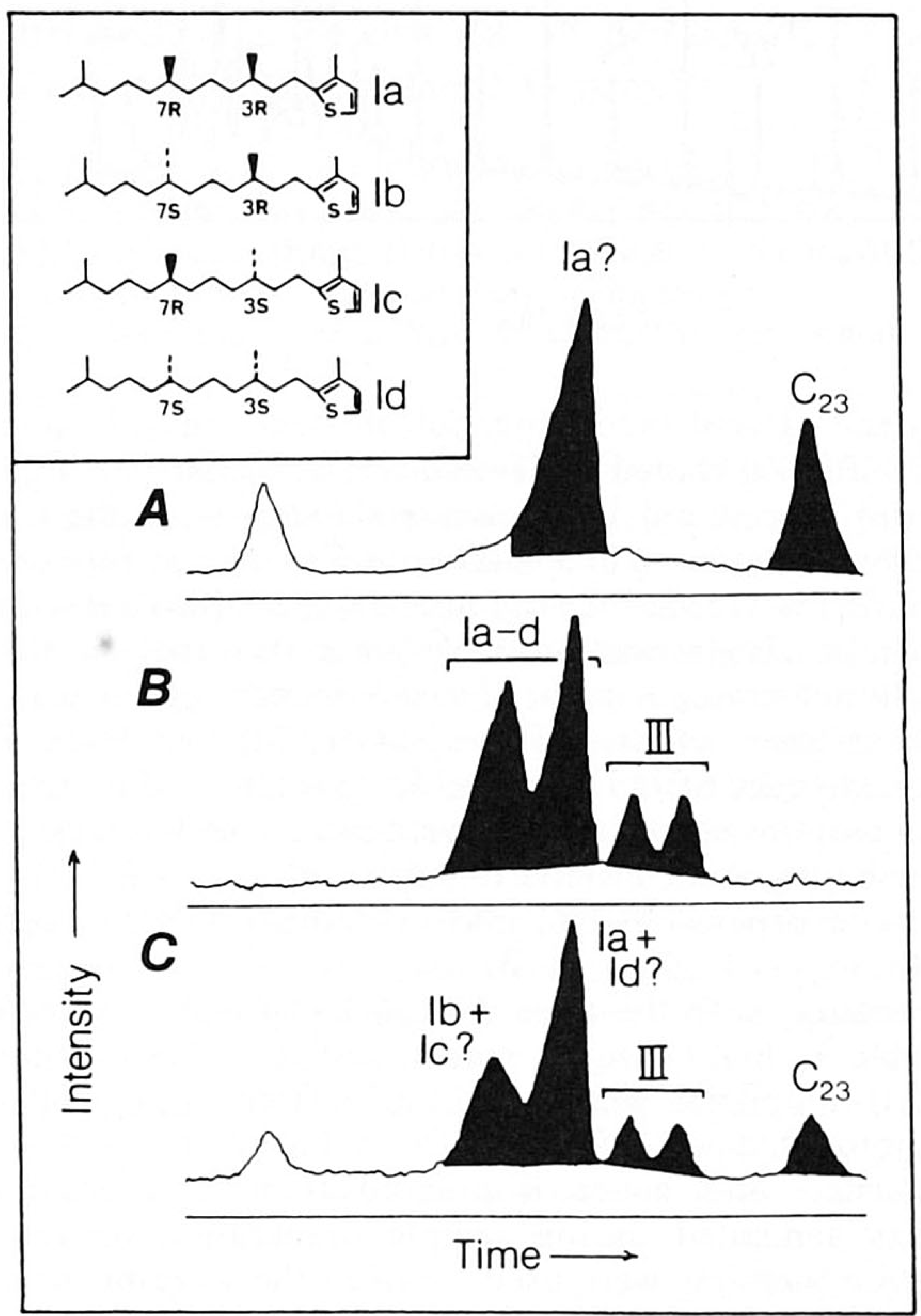

Fig. 4 Partial GC traces using a DEGS/PEGS column of the $n$-tricosane $\left(n-C_{23}\right)$ region of: $A$, aliphatic hydrocarbon fraction of a Pleistocene calcareous clay from the Cariaco Trench (DSDP 15-147C-3-3, 138-m sub-bottom depth). B, Products (I and III) of the synthesis shown in Fig. 3. $C$, Coinjection of $A$ and $B$. The naturally occurring thiophene enhances the latter peak attributed to I. This evidence can be compared with that from similar GC analyses of acyclic isoprenoids where the isomer with the stereochemistry corresponding to both that of the phytyl moiety in chlorophyll- $a^{30}$ and archaebacterial phytanyl ether moieties ${ }^{31}$ occurs in the peak with the greater elution time (for example 7R, $11 \mathrm{R}$ in dihydrophytol ${ }^{31-34}$ and phytanic $\mathrm{acid}^{32,34}$, and $6 \mathrm{R}, 10 \mathrm{~S}$ in phytane ${ }^{35}$ ).

Methods. 34-m DEGS/PEGS (3:1) glass capillary column fitted in Carlo Erba FTV2150 chromatograph programmed from 20$109^{\circ} \mathrm{C}$ at $4{ }^{\circ} \mathrm{C} \mathrm{min}^{-1}$ and held isothermally at $109^{\circ} \mathrm{C}$. Data are acquired and processed using a VG Minichrom data system. Assignment of $n-C_{23}$ was made by comparison with the elution position of a reference standard. Note that the elution times of the thiophenes relative to $n$-alkanes are markedly greater with this column than with that (OV-1) employed in the GC-MS analysis (Fig. 1). carbon cycles within sediments. Also, the occurrence of organosulphur compounds indicates that organic matter, like iron ${ }^{28}$, can act as a sink for sedimentary sulphur. Thus, the identification of acyclic isoprenoid thiophenes in sediments demonstrates a new, significant process in the diagenetic alteration of lipids, and presumably other compound classes.

S.C.B. and C.A.L. are grateful to NERC for GC-MS facilities (grants GR3/2951 and GR3/3758 to Professor G. Eglinton), to the Royal Society for an instrument grant (VG Minichrom system) and to British Petroleum PLC for a studentship (C.A.L.).

Received 2 September 1985; accepted 23 January 1986

1. Tissot, B. P. \& Welte, D. H. Petroleum Formation and Occurrence (Springer, Berlin, 1984). 2. Orr, W. L. Amer. chem. Soc. Div. Fuel. Chem. Preprints 22, 86-99 (1977).

3. Speers, G. C. \& Whitehead, E. V. in Organic Geochemistry: Methods and Results (eds Eglinton, G. \& Murphy, M. T. J.) 638-675 (Springer, Berlin, 1969)

4. Ho, T. Y., Rogers, M. A., Drushel, H. V. \& Koons, C. B. Bull. Amer. Ass. Petrol. Geol. 58 2338-2348 (1974)

5. Payzant, J. D., Cyr, T. D., Montgomery, D. S. \& Strausz, O. P. Tetrahedron Lett. 26, 4175-4178 (1985)

6. Valisolalao, J., Perakis, N. Chappe, B. \& Albrecht, P. Tetrahedron Lett. 25, 1183-1186 (1984).

7. Rullkötter, J., von der Dick, H. \& Welte, D. H. Init. Rep. DSDP 63, 819-836 (1981).

8. Rullkötter, J., von der Dick, H. \& Welte, D. H. Init. Rep. DSDP 64, 837-853 (1982)

9. Rullkötter, J., Mukhopadhyay, P. K. \& Welte, D. H. Init. Rep. DSDP 75, 1069-1087 (1984)

10. Rullkötter, J., Mukhopadhyay, P. K., Schaefer, R. G. \& Welte, D. H. Inst. Rep. DSDP 79, 775-806 (1984).

11. van Graas, G, thesis, Delft Univ. Technol. (1982)

12. Klok, J. thesis, Delft Univ. Technol. (1984).

13. ten Haven, H. L., de Leeuw, J. W. \& Schenck, P. A. Geochim. cosmochim. Acta 49, 2181-2191 (1985)

4. Dean, R. A. \& Whitehead, E. V. Tetrahedron Lett. 768-770 (1961)

15. Bendoraitis, J. G., Brown, B. L. \& Hepner, L. S. Analyt. Chem. 34, 49-53 (1962)

16. Brassell, S. C., Wardroper, A. M. K., Thomson, I. D., Maxwell, J. R. \& Eglinton, G. Nature 290, 693-696 (1981).

17. Chappe, B., Michaelis, W. \& Albrecht, P. in Advances in Organic Geochemistry 1979 (eds Douglas, A. G. \& Maxwell, J. R.) 265-274 (Pergammon, Oxford, 1980).

18. Risatti, J. B., Rowland, S. J., Yon, D. A. \& Maxwell, J. R. Org. Geochem. 6, 93-104 (1984)

19. Goossens, H., de Leeuw, J. W., Schenck, P. A. \& Brassell, S. C. Nature 312, 440-442 (1984).

20. Kinney, I. W. \& Cook, G. L. Analyt. Chem. 24, 1391-1396 (1952).

. Pomonis, J. G. Fatland, C. L. \& Zaylskie, R. G. J chem. Engng Data 21, 380-385 (1976).

22. Brassell, S. C. \& Eglinton, G. in Advances in Organic Geochemistry 1981 (eds Bjorøy, M. et al.) 684-697 (Wiley, Chichester, 1983).

23. Brassell, S. C. et al. in Advances in Organic Geochemistry 1979 (eds Douglas, A. G. \& Maxwell, J. R.) 375-392 (Pergamon, Oxford, 1980).

24. Mango, F. D. Geochim. cosmochim. Acta 47, 1433-1441 (1983),

25. Whelan, J. K., Hunt, J. M. \& Berman, J. Geochim. cosmochim. Acta 44, 1767-1785 (1980).

26. McKenzie, A. S., Patience, R. L., Yon, D. A. \& Maxwell, J. R. Geochim cosmochim. Acto 46, 783-792 (1982).

27. De Leeuw, J. W. et al. in Advances in Organic Geochemistry 1975 (eds Campos, R. \& Goni, J.) 61-79 (Enadisma, Madrid 1977).

28. Berner, R. A. Geochim. cosmochim. Acta 48, 605-615 (1984).

29. Brassell, S. C., Gowar, A. P. \& Eglinton, G. in Advances in Organic Geochemistry 1979 (eds Douglas, A. G. \& Maxwell, J. R.) 421-426 (Pergamon, Oxford, 1980).

30. Burrell, J. W. K., Garwood, R. F., Jackman, L. M., Oskay, E. \& Weedon, B. C. L. J. chem Soc. C., 2144-2154 (1966).

31. Anderson, R., Kates, M., Baedecker, M. J., Kaplan, I. R. \& Ackman, R. G. Geochim cosmochim. Acta 41, 1381-1390 (1977).

32. Brooks, P. W. \& Maxwell, J. R. in Advances in Organic Geochemistry 1973 (eds Tissot, B. P. \& Bienner, F.) 977-991 (Technip, Paris, 1974)

33. Van Vleet, E. S. \& Quinn, J. G. Geochim. cosmochim. Acta 43, 289-303 (1979)

34. Prahl, F. G., Eglinton, G., Corner, E. D. S. \& O'Hara, S. C. M. Science 224, 1235-1237 (1984).

35. Patience, R. L., Yon, D. A., Ryback, G. \& Maxwell, J. R. in Advances in Organic Geochemistry 1979 (eds Douglas, A. G. \& Maxwell, J. R.) 287-293 (Pergamon, Oxford, 1980). 